\title{
Teknik Massage Counterpressure terhadap Penurunan Intensitas Nyeri Kala I Fase Aktif pada Ibu Bersalin di RSUD. Dr. M.M Dunda Limboto Kabupaten Gorontalo
}

\author{
Endah Yulianingsih ${ }^{1}$ Hasnawatty Surya Porouw ${ }^{2}$ Suwarni Loleh $^{3}$ \\ 1,2 Jurusan Kebidanan Politeknik Kesehatan Kemenkes Gorontalo \\ ${ }^{3}$ Jurusan Keperawatan Politeknik Kesehatan Kemenkes Gorontalo \\ Email: endahyulianingsih@yahoo.com \\ Doi : https://doi.org/ 10.30787/gaster.v17i2.374 \\ Received: April 2019 | Revised: Mei 2019 | Accepted: July 2019
}

\begin{abstract}
ABSTRAK
Pendahuluan: Nyeri persalinan dapat menyebabkan timbulnya hiperventilasi sehingga kebutuhan oksigen meningkat, kenaikan tekanan darah, dan berkurangnya motilitas usus serta vesika urinaria. Keadaan ini akan merangsang peningkatan katekolamin yang dapat menyebabkan gangguan pada kekuatan kontraksi uterus sehingga terjadi inersia uteri. Apabila nyeri persalinan tidak diatasi akan menyebabkan terjadinya partus lama Metode: Desain penelitian Pre Eksperimen dengan menggunakan One Group Pretest-Posttest Design, populasi yaitu seluruh ibu bersalin yang ada di RSUD. Dr. MM Dunda Limboto dan sampel sebanyak 20 responden dengan tehnik Purposive Sampling sedangkan analisa data menggunakan uji Wilcoxon. Untuk menganalisa pengaruh tehnik masase counter pressure terhadap penurunan intensitas nyeri Kala I Fase Aktif pada ibu bersalin. Hasil penelitian: Berdasarkan penelitian didapatkan hasil $p$ value 0,000 < 0,05 yaitu ada pengaruh tehnik masase counter pressure terhadap penurunan intensitas nyeri Kala I Fase Aktif pada ibu bersalin. Kesimpulan: Ada pengaruh signifikan Tehnik massase counter pressure terhadap penurunana intensitas Nyeri Kala I Fase Aktif pada ibu bersalin di RSUD Dr M.M Dunda Limboto Kabupaten Gorontalo.
\end{abstract}

Kata Kunci: Tehnik Massase Counter pressure; Kala I Fase Aktif

\section{ABSTRACT}

Introduction: Pain of labor can cause hyperventilation so that oxygen needs increase, increase blood pressure, and decrease intestinal motility and urinary vesicles. This situation will stimulate an increase in catecholamines which can cause interference with the strength of uterine contractions resulting in uterine inertia. If labor pain is not overcome, it will cause long-term labor. Method: Pre-experimental research design using One Group Pretest-Posittest Design, the population is all maternity mothers in the RSUD. Dr. MM Dunda Limboto and a sample of 20 respondents with Purposive Sampling techniques while analyzing the data using the Wilcoxon 
test. To analyze the effect of counter pressure massage techniques on decreasing the intensity of pain during the active phase of maternity. The results of the study: Based on the research, it was found that the $p$ value was $0,000<0,05$, that is, there was the effect of counter pressure massage techniques on the decrease in the intensity of pain during the Active Phase of the mother. Conclusion: There is a significant influence of massase counter pressure technique on reducing the intensity of Active Phase Pain in the maternity at Dr M.M Dunda Limboto Hospital Gorontalo District.

Keywords: Counter pressure technique; first phase active

\section{PENDAHULUAN}

Persalinan adalah suatu proses pengeluaran hasil konsepsi (bayi dan Placenta) secara alami, yang dimulai dengan adanya kontraksi yang adekuat pada uterus, pembukaan dan penipisan serviks (Widiastini 2015). Nyeri persalinan merupakan kondisi fisiologis yang secara umum dialami oleh hampir semua ibu bersalin (Supliyani 2017).

Nyeri persalinan merupakan sebuah pengalaman subjektif disebabkan oleh iskemik otot uteri, penarikan dan traksi ligament uteri, traksi ovarium, tuba fallopii dan distensi bagian bawah uteri, otot dasar panggul dan perineum (M.A.R Kb, Hasnah 2019). Rasa nyeri pada persalinan merupakan manifestasi dari adanya kontraksi otot rahim. Tingkat nyeri persalinan digambarkan dengan intensitas nyeri yang dipersepsikan oleh ibu saat proses persalinan. Intensitas nyeri tergantung dari sensasi keparahan nyeri itu sendiri (Widiastini 2015).

Rasa nyeri pada persalinan muncul akibat respons psikis dan refleks fisik. Nyeri akan berdampak pada peningkatan aktivitas sistem saraf simpatik yang dapat mengakibatkan perubahan tekanan darah, denyut nadi, pernafasaan, dan warna kulit, mual muntah, dan juga keringat berlebihan. Perubahan tingkah laku tertentu akibat nyeri juga sering terlihat seperti peningkatan rasa cemas dengan pemikiran yang menyempit, mengerang, menangis, gerakan tangan dan ketegangan otot yang sangat di seluruh tubuh.

Ketegangan emosi akibat rasa cemas dan rasa takut dapat memperberat persepsi ibu terhadap nyeri selama persalinan. Nyeri persalinan akan menimbulkan ketakutan sehingga muncul kecemasan yang berakhir dengan kepanikan (Angraeni, Setyowati, and Wijayanti 2013). 
Nyeri persalinan juga dapat menyebabkan timbulnya hiperventilasi sehingga kebutuhan oksigen meningkat, kenaikan tekanan darah, dan berkurangnya motilitas usus serta vesika urinaria. Keadaan ini akan merangsang peningkatan katekolamin yang dapat menyebabkan gangguan pada kekuatan kontraksi uterus sehingga terjadi inersia uteri. Apabila nyeri persalinan tidak diatasi akan menyebabkan terjadinya partus lama (Anita 2017).

Hal ini akan menyebabkan ibu bersalin memiliki pengalaman persalinan yang buruk, mengalami trauma persalinan yang dapat menyebabkan postpartum blues, maka sangat penting untuk penolong persalinan memenuhi kebutuhan ibu akan rasa aman dan nyaman (Multi, Handayani, \& Arifin, 2007) (Ma'rifah 2014) Upaya pengurangan nyeri persalinan dengan cara non farmakologi adalah Masase Conterpresure dengan melakukan tekanan tangan pada jaringan lunak, biasanya otot, tendon atau ligamentum, tanpa menyebabkan gerakan atau perubahan posisi sendi untuk meredakan nyeri, menghasilkan relaksasi dan atau memperbaiki situasi (Rosalina 2017)

Fenomena yang terjadi saat ini kebanyakan ibu lebih memilih untuk melakukan operasi sectio caesarea tanpa indikasi yang jelas dan juga meminta untuk dilakukan epidural anestesi tanpa mempertimbangkan efek dari tindakan tersebut.Menurut Word Health Organitation (WHO), standar rata-rata sectio Caesarea disebuah negera adalah sekitar 5-15\% per 1000 kelahiran di dunia, rumah sakit pemerintah rata-rata $11 \%$, sementara di rumah sakit swasta bisa lebih dari 30\%. Pemerintah sectio caesarea (SC) disejumlah negara berkembang melonjak pesat setiap tahunnya.

Persalinan sectio caesarea di indonesia adalah sekitar $30-80 \%$ dari total persalinan. Angka kejadian sectio caesarea di indonesia menuerut data survey nasional 2007 adalah 927.000 dari 4.039.000 persalinan. Beberapa kerugian dari persalianan yang dijalani melalui sectio caesarea yaitu adanya komplikasi lain yang dapat terjadi saat tindakan dengan frekuensi diatas $11 \%$. Berdasarkan data yang diperoleh di indonesia terjadi peningkatan angka sectio caesarea disertai kejadian infeksi luka post sectio caesarea sekitar $90 \%$ dari morbiditas pasca operasi disebabkan oleh infeksi luka operasi (Oscar Primadi 2014).

Pusat Data Persatuan Rumah Sakit Seluruh Indonesia menjelaskan bahwa15\% ibu di Indonesia mengalami komplikasi persalinan 
dan $21 \%$ menyatakan bahwa persalinan yang dialami merupakan persalinan yang menyakitkan karena merasakan nyeri yang sangat, sedangkan $63 \%$ tidak memperoleh informasi tentang persiapan yang harus dilakukan guna mengurangi nyeri pada persalinan (Yuliasari et al. 2015)

Data Dinas Kesehatan Provinsi Gorontalo yang didapatkan pada Studi Pendahuluan, terdapat ibu bersalin Provinsi Gorontalo pada tahun 2014 berjumlah 21.655, kemudian pada tahun 2015 tercatat 21.997, sementara pada tahun 2016 data ibu bersalin berjumalh 23.997. untuk data ibu bersalin wilayah Kabupaten gorontalo pada tahu 2014 tercatat sejumlah 7.159, kemudian pada tahun 2015 tercatat 7,159 dan pada tahun 2016 tercatat sejumlah 7.871 .

Berdasarkan pengumpulan data awal di bagian rekam medik RSUD Dr. M.M Dunda Limboto tahun 2017 ibu bersalin berjumlah 1.581 dengan persalinan SC berjumlah 443. Berdasarkan wawancara awal dengan salah satu Bidan yang bertugas di ruang bersalin, bidan mengatakan bahwa belum ada intervensi atau tehnik yang diterapkan untuk mengurangi rasa nyeri pada ibu bersalin di RSUD Dr. M.M Dunda Limboto.
Gambaran permasalahan yang telah dipaparkan diatas memberikan informasi bahwa nyeri persalinan yang tidak dapat diatasi oleh ibu akan berdampak pada psikologis, proses persalinan dan jenis persalinan, sehingga penanganan nyeri dalam persalinan merupakan hal utama yang harus diperhatikan oleh pemberi asuhan melalui tehnik pengontrolan nyeri salah satunya adalah tehnik masase counter pressure.

\section{BAHAN DAN METODE}

Jenis penelitian ini adalah pra eksperimen dengan desain One Group Pretest- Posttest Design. Penelitian ini dilaksanakan pada bulan Mei sampai Juni 2018 di RSUD Dr MM Dunda Limboto.

Populasi pada penelitian ini adalah seluruh ibu inpartu kala I fase aktif. Tehnik pengambilan sampel dalam penelitian ini menggunakan tehnik accidental sampling. Dimana tehnik pengambilan sampel ini diperoleh secara kebetulan tanpa direncana oleh peneliti ditempat penelitian sebanyak 20 ibu bersalin. Prosedur pengumpulan data, untuk variabel bebas menggunakan tehnik massase counter pressure menggunakan lembar ceklist dan variabel terikat nyeri persalinan menggunakan 
NRS (Numeric raiting scale) menggunakan lembar observasi

Analisa bivariat menggunakan hasil pre test dan post test dengan menggunakan uji normalitas menggunakan uji Wilcoxon. Untuk menganalisa pengaruh efektifitas tehnik massase counter pressure terhadap intensitas nyeri kala I fase aktif pada ibu bersalin.

\section{HASIL DAN PEMBAHASAN}

\section{Karakteristik Responden}

a. Data tabel 1. Distribusi Frekwensi Responden Bedasarkan Umur

\begin{tabular}{ccc}
\hline Umur & $\mathbf{f}$ & $\mathbf{\%}$ \\
\hline$<20$ Tahun & 11 & 28.2 \\
$20-35$ & 5 & 12.8 \\
$>35$ & 4 & 10.3 \\
\hline Jumlah & 20 & 100.0 \\
\hline
\end{tabular}

*Data sumber, 2018

Berdasarkan data tabel 1 menunjukan bahwa sebagian besar responden berumur $<20$ tahun berjumlah 11(28,2\%) dan sebagian kecil responden berumur $>35$ tahun berjumlah $4(10,3 \%)$.

Menurut teori Judha (2012) umur ibu dapat mempengaruhi reaksi nyeri pada persalinan. Umur dapat dikaitkan dengan kematangan organ reproduksi dan kesiapan psikologis dalam menghadapi proses persalinan.
Umur yang relatif muda secara psikologis memiliki faktor stressor yang tinggi terutama dalam mentoleransi rangsangan nyeri yang dirasakan sehingga seringkali meningkatkan persepsi nyeri atau sebaliknya nyeri juga dapat menimbulkan perasaan ansietas atau stress (J.Adam and Umboh 2015).

Sedangkan pada ibu yang berumur $>35$ tahun memiliki pengaruh yang kuat terhadap respon nyeri, hal ini disebabkan pengalaman melahirkan sebelumnya. Pada umur $>35$ tahun fungsi organ-organ reproduksinya semakin menurun selain itu usia ini merupakan usia faktor risiko yang dapat mempengaruhi psikologis ibu dalam persalinan.

Kecemasan dapat dihubungkan dengan faktor umur ibu, dimana umur dapat memberi dampak terhadap perasaan takut dan cemas yaitu di bawah usia 20 tahun serta di atas 31 - 40 tahun karena usia ini merupakan usia kategori kehamilan beresiko tinggi dan seorang ibu yang berusia lebih lanjut akan menanggung resiko yang semakin tinggi untuk melahirkan bayi cacat lahir dengan sindrom down (Widyastuti, Apriana, and R 2011).

Hal ini sejalan dengan hasil penelitian yang dilakukan oleh A.D Puspita (2013) bahwa terdapat hubungan yang signifikan antara umur terhadap nyeri persalinan (D.Puspita 2013) 
b. Data tabel 2 : Distribusi Responden berdasarkan Pendidikan

\begin{tabular}{|c|c|c|}
\hline Umur & f & $\%$ \\
\hline SD & 15 & 75.0 \\
\hline SMP-SMA & 3 & 15.0 \\
\hline Perguruan Tinggi & 2 & 10.0 \\
\hline Jumlah & 20 & 100.0 \\
\hline
\end{tabular}

*Data sumber, 2018

Berdasarkan data tabel 2 Hasil penelitian ini menunjukan bahwa sebagian besar responden memiliki pendidikan SD berjumlah 15 (75\%) dan responden dengan pendidikan Tinggi berjumlah 2 (10\%).

\section{Analisis Univariat}

Data Tabel 3: Distribusi Intensitas Nyeri Sebelum Dilakukan Tehnik Massase Counter Pressure Di RSUD. MM.Dunda Limboto

\begin{tabular}{lcc}
\hline \multicolumn{1}{c}{ Tingkat Nyeri } & $\mathbf{f}$ & $\mathbf{\%}$ \\
\hline Nyeri Sedang & 5 & 25.0 \\
Nyeri Berat & 10 & 25.0 \\
Nyeri Sangat & 5 & 50.0 \\
Berat & & \\
\hline Jumlah & 20 & 100.0 \\
\hline
\end{tabular}

*Data sumber 2018

Berdasarkan tabel 3 menunjukan sebelum dilakukan massase counter pressure terdapat sebagian besar responden mengalami nyeri berat sebanyak 50.0\% .
Hasil penelitian ini sejalan dengan hasil penelitian yang dilakukan oleh Ersila W et all (2019) yang menunjukkan bahwa Nyeri persalinan pada responden sebelum dilakukan massage effleurage sebagian besar mengalami nyeri berat $(73,3 \%)$ dan setelah dilakukan massage effleurage, lebih dari separuh responden menunjukkan penurunan nyeri menjadi nyeri ringan $(53,3 \%)$ dan nyeri sedang $(46,7 \%)$. (Ersila, Prafitri, and Zuhana 2019)

Hasil penelitian ini didukung oleh Teori yang dikemukan oleh Sondakh, J (2013) bahwa persalinan dimulai dari adanya kontraksi uterus yang teratur yang menyebabkan penipisan dan dilatasi serviks sehingga hasil konsepsi dapat dikeluarkan. Kontraksi inilah yang menimbulkan rasa nyeri selama kala I persalinan. Penyebab nyeri terutama akibat dari rangsangan reseptor-reseptor adnexa, uterus dan ligamen-ligamen. kombinasi peregangan segmen bawah rahim dan iskemia otot-otot Rahim (Yanti, 2009).

Pada sebagian ibu bersalin akan mengalami rasa nyeri pada waktu melahirkan, namun intensitas rasa nyeri berbeda pada setiap ibu bersalin. Hal ini dapat mempengaruhi kelelahan 
dan kecemasan yang selanjutnya akan menimbulkan ketegangan, menghalangi relaksasi bagian tubuh lainnya dan dapat menyebabkan exhaustion, sehingga mengakibatkan peningkatan nyeri pada kala I.

Data Tabel 4: Distribusi Intensitas Nyeri Sesudah Dilakukan Tehnik Massase Counter Pressure Di RSUD. MM.Dunda Limboto

\begin{tabular}{lcc}
\hline \multicolumn{1}{c}{ Tingkat Nyeri } & f & \% \\
\hline Nyeri Ringan & 7 & 35.0 \\
Nyeri Sedang & 9 & 45.0 \\
Nyeri Berat & 4 & 20.0 \\
\hline Jumlah & 20 & 100.0
\end{tabular}

*Data sumber 2018

Berdasarkan tabel 4 menunjukan sesudah dilakukan massase counter terdapat responden yang mengalami Nyeri sedang sebanyak $35 \%$, dan responden yang mengalami nyeri berat sebanyak $20 \%$.

Hasil penelitian ini sejalan dengan Hasil penelitian yang dilakukan oleh Satria 2018 yang menunjukan hasil bahwa terdapat penurunan intensitas nyeri pada ibu bersalin kala I fase aktif yaitu dari nyeri berat ke nyeri ringan setelah dilakukan setelah dilakukan tehnik masase counter pressure (Satria 2018).

Menurut cuninham (2006) bahwa Pengurangan rasa nyeri pada ibu bersalin dapat dintervensi untuk mengurangi ketidaknyamanan (nyeri) selama persalinan adalah dengan intervensi non-farmakologi. Salah satu tehnik pengurangan rasa nyeri pada persalinan adalah dengan tehnik counterpreasure, tehnik counterpreusure pada penelitian ini adalah dengan memberikan tekanan yang terus menerus selama kontraksi dilakukan pada tulang sacrum wanita dengan kepalan salah satu tangan (Kuswanti I dan Melina, 2014).

\section{Analisis Bivariat}

Tabel 5. Analisis pengaruh tehnik massase counter pressure terhadap intensitas nyeri kala I fase aktif sebelum dan sesudah intervensi

\begin{tabular}{lllll}
\hline \multicolumn{1}{c}{ Variabel } & N & Mean & Std.D & Sig \\
\hline $\begin{array}{l}\text { Nyeri } \\
\text { Persalinan }\end{array}$ & & & & \\
Pretest & 20 & 3.00 & 0.725 & 0.000 \\
Posttest & 20 & 1.85 & 0.745 & 0.000 \\
\hline
\end{tabular}

*Data sumber 2018

Pada tabel 5 menunjukkan bahwa nilai rata-rata nyeri persalinan sebelum diberikan perlakuan massase counter 
ISSN: 1858-3385, EISSN: 2549-7006

GASTER Vol. 17 No. 2 Agustus 2019

pressure adalah 3.00 dan rata-rata setelah diberikan perlakukan massase counter pressure adalah 1.15. Hasil perhitungan dengan menggunakan wilcoxon diperoleh nilai p 0.000 yang lebih kecil dari $\alpha 0.05$ dengan demikian sehingga Ho ditolak dan Ha diterima, artinya Dengan demikian massase counter pressure yang diberikan pada inpartu kala I fase aktif memiliki efektifitas.

Efektifitas massase counter pressure terhadap intensitas nyeri kala I fase aktif Sebelum dan Sesudah Intervensi menunjukkan hasil rata-rata nyeri persalinan sebelum diberikan perlakukan massase counter pressure adalah 3.00 dan rata-rata setelah diberikan perlakukan massase counter pressure adalah 1.85 hasil tersebut menunjukan bahwa setelah dilakukan massase counter pressure maka nyeri persalinan dirasakan oleh responden mengalami penurunan. Hasil uji statistik dengan wilcoxon didapatkan nilai Sig. 0.000 dengan demikian $p$ lebih kecil dari $\alpha(5 \%)$ atau 0.05 sehingga Ho ditolak dan Ha diterima, maka ada efektifitas massase counter pressure terhadap intensitas nyeri kala 1 fase aktif.
Hasil ini sejalan dengan teori Melzack dan Wall (1965) yang mengatakan bahwa stimulasi ringan secara actual dapat menghambat sensasi nyeri Artinya bahwa massase counter pressure atau pijatan adalah penekanan tulang sakrum akan memberikan rasa nyaman pada ibu selama tahapan pertama persalinan dalam menurunakan nyeri secara efektif. massase counter pressure atau pijatan adalah penekanan tulang sakrum akan memberikan rasa nyaman pada ibu selama tahapan pertama persalinan dalam menurunkan nyeri secara efektif (Fraser, Diane M, Dkk. 2009, Maryunani, 2010).

Terkait dengan hasil Penelitian lainnya yang dilakukan oleh Rezeki dkk (2013) tentang tingkat nyeri pinggang kala I persalinan melalui tehnik BackEffluergage dan Counter Preusure menunjukkan teknik Counter Pressure memberikan hasil selisih mean 3,63 yang artinya lebih besar dibandingkan dengan nilai mean teknik Back-Effleurage yaitu 2,92 .

Berdasarkan hasil penelitian tersebut menunjukkan bahwa masase counterpressure merupakan tehnik 
masase yang memiliki kontribusi dalam mengurangi nyeri persalinan kala I fase aktif. Masase counter pressure dalam penelitian ini dilakukan selama ibu mengalami kontraksi. Massase counter pressure dilakukan dengan memberikan penekanan pada area nyeri yang dirasakan oleh ibu saat persalinan. Tekanan yang diberikan bergantung kepada intensitas nyeri yang dialami oleh ibu. Keras atau tidaknya tekanan cukup dengan melihat ekspresi yang ditampakkan oleh ibu saat persalinan (Wardani, R.A dan Herlina 2017).

Dengan pemberian masase teknik counter pressure dapat menutup gerbang pesan nyeri yang akan dihantarkan menuju medulla spinalis dan otak, selain itu tekanan kuat pada teknik ini dapat mengaktifkan senyawa endrophine yang berada di sinaps sel-sel saraf tulang belakang dan otak, sehingga transmisi dari pesan nyeri dapat dihambat dan menyebabkan status penurunan sensasi nyeri.

Tujuan utama dari massase ini adalah untuk mengalihkan rasa nyeri yang dialami ibu bersalin dengan menekan bagian tubuh yang terasa nyeri. Prinsip dasar yang dari massase counterpressure adalah melakukan pemijatan secara terus menerus. Dengan adanya pengalihan rasa nyeri yang dialami saat persalinan diharapkan persalinan dapat berjalan dengan lebih cepat dan semakin menurunkan resiko akibat terjadinya persalinan lama.

Hal ini dapat terjadi dengan beberapa kemungkinan diantaranya adalah kebenaran Teori Gate Kontrol. dikarenakan bahwa tehnik massase countrepeseur dapat menstimulasi dan merangsang kemampuan untuk mengurangi dan meningkatkan derajat perasaan nyeri melalui mekanisme hambatan neural atau spinal terjadi dalam substansi gelatinosa yang terdapat dikornu dorsal medulla spinalis sel-sel transmisi memproyeksikan pesan nyeri ke otak (Pasongli, S.,dkk. 2014).

Impuls saraf yang diterima oleh nosiseptor, reseptor dipengaruhi oleh masase counterpreusure. Pijatan atau sentuhan yang dilakukan akan menghambat menentukan apakah impuls saraf dapat berjalan bebas atau tidak ke medulla dan thalamus sehingga dapat mentransmisikan impuls atau pesan sensori ke korteks 
sensorik. Jika penghambat tersebut tertutup maka sensasi nyeri akan berkurang (Fraser, Diane M, Dkk. 2009)

Berdasarkan hasil penelitian tersebut peneliti berasumsi bahwa tehnik masase counter pressure yang dilakukan selama ibu mengalami kontraksi, dengan tehnik pijatan tulang sakrum dengan menggunakan kepalan tangan dapat menghambat dan mengurangi psikologis dalam persepsi nyeri, termasuk motivasi untuk bebas dari nyeri, dan peranan pikiran, emosi, dan reaksi stress. Melalui model ini, dapat dimengerti bahwa nyeri dapat dikontrol oleh manipulasi non farmakologis maupun intervensi psikologis.

\section{KESIMPULAN DAN SARAN}

Kesimpulan berdasarkan hasil penelitian, dapat disimpulkan bahwa:

1. Karakteristik responden penelitian ini terdapat $28,2 \%$ responden berada pada umur $<20$ tahun dan $10,3 \%$ berada pada umur $>35$ tahun.

2. Tingkat nyeri sebelum dilakukan tindakan massage countrepreasure pada ibu bersalin kala I fase aktif di RSUD. MM Dunda
Limbota adalah dengan tingkat nyeri berat terdapat $50 \%$

3. Tingkat nyeri setelah dilakukan tindakan massage ountrepreasure pada ibu bersalin kala I fase aktif di RSUD. MM Dunda Limbota adalah dengan tingkat nyeri sedang terdapat $45 \%$

4. Ada pengaruh massage ountrepreasure terhadap penurunan tingkat nyeri pada ibu bersalin kala I fase aktif di RSUD. MM Dunda Limbota dengan $p$ value $0,000<\alpha$ 0.05 .

\section{Saran}

Disarankan bagi Bidan yang berada di RSUD. MM Dunda Limboto agar dapat membuat standar operasional prosedur teknik counter pressure sebagai salah satu upaya asuhan kebidanan terkini dalam rangka asuhan saying ibu.

Rekomendasi hasil penelitian ini adalah agar dalam memberikan asuhan kepada ibu hamil dalam menghadapi bidan dapat membantu memenuhi kebutuhan ibu akan rasa nyaman dalam pengontrolan nyeri secara non farmakologis saat memberikan pertolongan persalinan dengan menerapkan teknik Counterpressure. 


\section{DAFTAR PUSTAKA}

Angraeni, Pratiwi Diah, Heni Setyowati, and Kartika Wijayanti. 2013. "Efektifitas Teknik Abdominal Lifting Dan Counter Pressure Effectiveness Technic of Abdominal Lifting and Counter Pressure in the Fight Labor Pains Active Phase I At General Goverment Tidar Hospital Magelang." Artikel Penelitian Universitas Muhammadiyah Magelang 31.

Anita, Wan. 2017. "Techniques of Pain Reduction in the Normal Labor Process : Systematic Review." Jurnal Endurance 2(3): 362.

D.Puspita, Anisyah. 2013. Analisis Faktor-Faktor Yang Mempengaruhi Nyeri Persalinan Pada Ibu Bersalin Kala I Fase Aktif Di Puskesmas Mergangsang Tahun 2013 Skripsi.

Ersila, Wahyu, Lia Dwi Prafitri, and Nina Zuhana. 2019. "Perbedaan Efektivitas Massage Efflurage Dan Kompres Dingin Terhadap Nyeri Persalinan Di Puskesmas Kabupaten Pekalongan Jurnal SIKLUS Volume 08 Nomor 02 , Juni 2019.” 8: 107-15.

J.Adam, and J.M.L. Umboh. 2015. “Hubungan Antara Umur, Parietas Dan Pendampingan Suami Dengan Intensitas Nyeri Persalinan Kala I Fase Aktif Deselarasi Di Ruang Bersalin RSUD Prof . Dr . H . Aloei Saboe Kota Gorontalo Correlation between Age, Parity and Husband Assistance with Childbirt." Jikmu 5: 406-13.

Judha dkk, 2012, Teori Pungukuran Nyeri dan Nyeri Persalinan, Nuha Medika, Yogyakarta Kuswanti I dan Melina (2014). Askeb II Persalinan. Pustaka pelajar. Yogyakarta.

Maryunani, Anik. (2010). Nyeri Dalam Persalinan. Jakarta: Trans Info Media

M.A.R Kb, Hasnah, Muaningsih. 2019. "Literatur Review: Tinjauan Tentang Efektifitas Terapi Non Farmakologi Terhadap Penurunan Intensitas Nyeri Persalinan Kala I.” Journal of Islamic Nursing 3(2): 45.

Ma'rifah, Surtiningsih. 2014. "Efektifitas Tehnik Counter Pressure Dan Endorphin Massageterhadap Nyeri Persalinan Kala 1 Pada Ibu Bersalin Di Rsud Ajibarang.” Prosiding Seminar Nasional 5: 2-9. http://jurnal.unimus.ac.id/index.php/psn12012010/article/view/1255.

Oscar Primadi, Dkk. 2014. 14 Profil Kesehatan Indonesia Tahun 2013. jakarta: Kementerian Kesehatan RI. 
ISSN: 1858-3385, EISSN: 2549-7006

GASTER Vol. 17 No. 2 Agustus 2019

rejeki sri, nurullita ulfa, krestanti retno. "Tingkat Nyeri Pinggang Kala I Persalinan Melalui Teknik." 1(2): 124-33.

Rosalina. 2017. "Pengaruh Massage Effleurage Terhadap Pengurangan Rasa Nyeri Pada Persalinan Kala I Fase Aktif the Effect of Effleurage Effect on Reduce Possible Through Labor At I of Active Phase." CARING 1(272): 55-61.

Satria, M. 2018. "Pengaruh Sebelum Dan Sesudah Dilakukan Pijat Punggung Tehnik Counterpressure Terhadap Pengurangan Rasa Nyeri Ibu Bersalin Kala I Fase Aktif Di Klinik Bidan Elviana Tahun 2017.” XII(5).

Supliyani, Elin. 2017. "Pengaruh Masase Punggung Terhadap Intensitas Nyeri Persalinan Kala I Di Kota Bogor.” Bidan 3(1): 22-29.

Wardani, Riska Aprilia, and Herlina. 2016. "Efektivitas Massage Effleurage Dan Massage Counterpressure Terhadap Penurunan Nyeri Persalinan.” Jurnal Keperawatan dan Kebidanan 1(Imd): 19-25.

Widiastini, Luh Putu. 2015. Buku Ajar Asuhan Kebidanan Pada Ibu Bersalin Dan Bayi Baru Lahir. Bogor: In Media.

Widyastuti, Cahyani, Rista Apriana, and R. 2011. Hubungan Pengaetahuan Ibu Tentang Persalinan Kala I Dengan Kecemasan Persalinan Kala I Pada Ibu Bersalin DI RSIA Bahagia Semarang.

Yanti. 2009.Asuhan Kebidanan persalinana. Pustaka Rihana. Yogyakarta

Yuliasari, Dewi et al. 2015. "Hubungan Counterpressure Dengan Nyeri Persalinan Pada Ibu Bersalin Kala I Fase Aktif Ibu Primipara Di BPS Hj. SULASTRI, Amd.Keb Pekalongan Lampung Timur Tahun 2013." Februari 1(2015): 9-12. 